\title{
Islamic Law Overview on The Cashback System and The Use of Shopee Coins in Buying Transactions in The Shopee Application
}

\author{
Alfan Syafi'i ${ }^{1}$, Dina Madinah², Dedeh Nurdaimah ${ }^{3^{*}}$ \\ ${ }^{1,2,3^{*}}$ Husnul Khotimah Islamic College, Indonesia \\ Corresponding Author: dedehnurdaimah5@gmail.com ${ }^{3 *}$
}

Keywords : Islamic Law Review, Cashback System, Shopee Coin Users, Buying and Selling Transactions

\begin{abstract}
This study uses a descriptive qualitative method because it describes the data in the form of a written description. Types and sources of data in this study using primary and secondary data. Data collection techniques through interviews, observation, and documentation. The data obtained in this study are conclusions from various processes in qualitative research. Starting from data collection, selecting appropriate data, presenting data and then concluding.

The results of this study are in a review of Islamic Law, the provision of cashbacak promos by shopee parties to users is limited to giving gifts, as a marketing strategy to attract as many customers/users of the application as possible. And the use of shopee coins as discounted prices in buying and selling transactions is allowed, because the shopee coins used are obtained from cashback at the time of the previous transaction and the cashback is allowed.
\end{abstract}




\section{Introduction}

The large number of internet users in Indonesia is a potential for the national digital economy. So that E-Commerce, online stores, and other businesses based on communication/internet technology have emerged (Fauziah, 2020). One of the E-Commerce that is currently developing and in demand by the public is through the Marketplace. Marketplace is an online business transaction platform that provides electronic methods to facilitate commercial transactions such as selling goods, services or information online between buyers and sellers (Yunanto, 2020). Marketplace can also be interpreted as a virtual market where sellers and buyers meet each other to conduct transactions like the market in general, Marketplace provides space for sellers to market their products (Sutjipto \& Cahyono, 2020). In Islam Marketplace is known as Broker/Simsaroh. Brokers are liaisons/intermediaries between sellers and buyers to facilitate buying and selling (Khosyi'ah, 2014).

One of the marketplaces that is widely used by the public is the Shopee.co.id application. Shopee is an E-Commerce site owned by the SEA Group, previously known as Gerena. Founded in 2009 by Forest Li and headquartered in Malaysia, Thailand, Taiwan, Indonesia, Vietnam and the Philippines (Gatot \& Iwan, 2020).

Shopee is an online shopping application that can be accessed with smartphones so that it will be easier for people to shop or sell goods directly on their cellphones. The platform offers a great variety of products, and comes with secure payment methods. In addition, Shopee also offers a variety of interesting features that users can use to make transactions easier, one of which is direct payment or Cash On Delivery (COD), so buyers can make payments after the goods arrive directly without having to transfer money. first (Lestari et al., 2019).

Based on the data obtained by the author, the advantages of the Shopee application are many compared to other applications, one of which is the chat feature so that buyers can interact directly with sellers without having to communicate with other applications such as WA, LINE, BBM etc. Shopee also always provides free shipping promos, flash sales, discounted prices and games that can generate gold coins, as well as various other interesting promos.

One of the interesting programs currently in great demand by Shopee application users is the Cashback feature in the form of Shopee gold coins. Cashback is an immediate refund or deposit in the form of a balance after making a transaction. In another sense, cashback is an offer where the buyer is given a percentage of cash or virtual money or even a product but meets certain purchase conditions that have been set by the cashback organizer (Pratama et al., 2019).

Based on the data obtained by the author from the shopee application, in this Shopee application the cashback given is in the form of Shopee gold coins, where buyers first claim vouchers to get Cashback, then when making buying and selling transactions use the voucher so that later Cashback in the form of Shopee gold coins will Log in to our account after the purchase is complete. These Shopee coins can later be used as a discount when making the next transaction. However, this Cashback can only be used with the condition that transaction 
payments must go through the Shopee digital wallet or commonly called ShopeePay and must reach a minimum spend, so it is not free to use.

However, from the convenience and benefits that are obtained, people do not know in detail how the Cashback system and the use of Shopee coins and the mechanism and terms used are in accordance with Islamic law? considering that a transaction like this is a modern transaction, and of course there is no evidence that it is permissible or not. Therefore, the author will examine in terms of Islamic Law and make Islamic Law as a knife of analysis in reviewing this transaction with the research title: "Review of Islamic Law Against the Cashback System and the Use of Shopee Coins in Buying and Selling Transactions on the Shopee Application".

\section{Research Method}

Research methods

The research method used in this study is a qualitative research method. This qualitative research was chosen by the author based on the research objective who wants to get an overview of the Cashback transaction mechanism and the use of Shopee coins in buying and selling transactions on the Shopee application. By carrying out a research approach that combines between combining field research (field research) and library research (Library research). Field research (field research) is research that is carried out systematically by lifting data in the field.

\section{Data Types and Sources}

This research is a qualitative research with a descriptive approach, namely to obtain an overview in the field regarding the cashback system and the use of shopee coins in the shopee marketplace. The type of data used in this study is qualitative data type, namely the type of data in the form of text, photos, stories, images, artifacts and not in the form of calculations (Raco, 2010). The type of data required is in the form of documentation related to Cashback transactions and the use of Shopee coins which can be obtained directly from the Shopee application, and several statements from the results of interviews with Shopee application users. The data can be collected using data collection tools as support, including: cellphones (mobile phones), starter packs and quotas as data collection tools through observation and paper, stationery (pen) and voice recorder to support data collection through interviews. The tool is used by researchers directly to obtain data in the field, because the researchers themselves are as data collection instruments.

\section{Data collection technique}

In this study the author uses several methods to obtain data, the methods used include:

1. Observation. This method is used by researchers becoming direct application users and conducting transactions using the Cashback promo, so that they can find out in real 
terms how the Cashback system and the use of Shopee coins are in the Shopee application.

2. Interview. This interview was conducted with parties who are Shopee users and often take advantage of the Cashback promo on the Shopee application, this is done so that researchers know from the user's point of view in more depth by asking several questions.

3. Documentation. To obtain documentation as research support, the researchers conducted documentation related to transactions and the use of Cashback and Shopee coins. In this case, the researcher captures (screenshots) of every transaction on the Shopee application so that the Cashback system and the use of Shopee coins are clearly explained.

\section{Data analysis}

The data obtained in this study are conclusions from various processes in qualitative research. Starting from data collection, selecting appropriate data, presenting data and then concluding. After the process of concluding the data, there will be research results, namely new findings on a problem. Where the findings are in the form of a description of a problem that needs a solution so that it can be solved clearly. And this analysis is used by researchers to analyze the Islamic Law Review on the Cashback System and the Use of Shopee Coins in Buying and Selling Transactions on the Shopee Application.

\section{Result and Discussion}

According to Dr. Oni Sahroni in his book Fiqh Muamalah Contemporary which discusses the problem of Contemporary Economics states that, there are several provisions related to the provision of cashback including: a) if the cashback occurs in a sale and purchase transaction/lease/profit sharing (accepted by the buyer/tenant/capital owner), then the cashback permitted in Islam on condition that it is not an interest-bearing loan; b) if cashback is received by the creditor in a debt transaction, then if it is required it will be usury, but if it is not required it will be a gift. The explanation is as follows: cashback is an offer in which the buyer is given a percentage of cash or virtual money or even given a product but by fulfilling certain purchase conditions that have been determined by the cashback organizer (Sahroni, 2019).

According to figh, the cashback provisions are in accordance with the following two conditions: first, if the cashback occurs in a sale-purchase/lease/profit sharing transaction (cashback is given by the manager in a profit-sharing contract, the party who rents it out in an ijarah agreement, the seller in a sale-purchase contract). So cashback is allowed in Islam on the condition that it is not a mode (engineering) of interest-bearing loans and the clarity of the price of the goods being traded. In addition, there is no argument (nash) that prohibits cashback in the transaction, so the basic rules apply: 


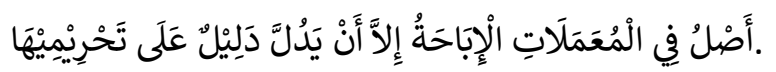

Meaning: "In principle, in muamalah it is permissible unless there is evidence that forbids it".

Furthermore, DSN MUI Fatwa No: 86/DSN-MUI/XII/2012 concerning Prizes in Funding for Islamic Financial Institutions; stipulates that the prize must not be in the form of money, so as not to become an engineering practice of interest-bearing loans (DSN MUI, 2000). In fiqh, the cashback that is allowed above is categorized as giving up some of its rights (at-tanazul 'anil haq) in the context of promotions and part of marketing. Second, the cashback given by the borrower in the debt transaction if it is required to become interest in accordance with the following rules:

$$
\text { كُلُْ قَرضِ جَرَّ مَنْفَعَة فَهُهَ رِيَا. }
$$

It means: "That every benefit received by the creditor for his loan services to the debtor is included in usury" (Sahroni, 2019).

In practice, the provision of cashback promos by Shopee is as a gift to users, and is a marketing strategy carried out by Shopee to increase user interest using the Shopee application. However, there are several conditions that must be met by users, one of which is that users make payments via Shopee digital money or commonly called ShopeePay. In Islam this is allowed, provided that: a) funds placed by users in digital wallets, if used by publishers, the discount given is at the initiative of the publisher (without conditions), b) funds placed by users in digital wallets are not used by publishers. If the funds are used by the issuer with the required discount, then it becomes usury. The contract that occurs in this transaction can be a deposit and can be a loan. It becomes a deposit if the publisher does not use the user's funds stored in the digital money. However, if the publisher uses the money, the contract becomes the issuer's debt to the user (Sahroni, 2020).

Based on the results of interviews conducted with sister Siffa Khoerunisa as a shopee application user, it can be concluded that any money stored in digital money is never used by the shopee and its status is just a deposit, thus payment using shopeepay which is emphasized by the publisher is only limited to making it easier users in conducting transactions (Siffa Khoerunisa, Interview 10 July 2021).

Based on the explanation above, it can be concluded that the gift of cashbacak promos by shopee to users is limited to giving gifts, as a marketing strategy to attract as many customers/users of the application as possible. The results of this study are also in accordance with the results of previous research, namely by Novera (2020) in his research allowing the provision of cashback on non-cash buying and selling motorcycle transactions in the perspective 
of Islamic law. Giving cashback is allowed because the transactions carried out are non-cash transactions so that there is a consumer's debt to the seller, and this cashback is given as a relief in the debt payment process. And there is clarity on prices and not engineering transactions (manipulation) (Novera, 2020).

In addition, in Rusmana's research, Nasrullah and Hani (2019) also allow cashback, but in this study cashback is given in payment transactions on the Gopay application, this transaction is almost the same as payment transactions that occur in the Shopee application, and cashback is allowed because cashback is a form of payment. gifts given by digital money issuers as gifts for users as a marketing or promotion strategy (Rusmana et al., 2019).

In Islam, giving gifts is certainly allowed with the aim of glorifying someone, as contained in the argument that will be described below:

1. Al-Qur'an

Al-Qur'an Surah Amn-Naml verse 35:

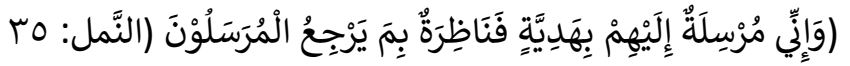

Meaning: "And verily I will send messengers to them with (bring) gifts, and (I will) wait for what the messengers will bring back" (Surah An-Naml: 35).

2. Hadith

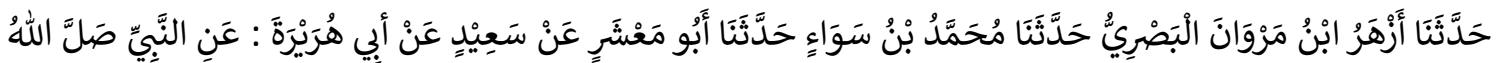

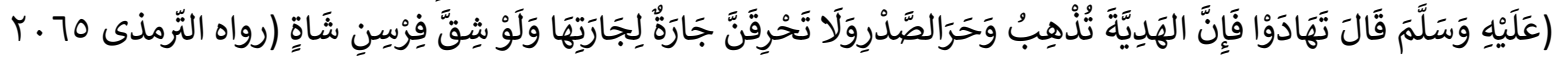

"Has told us Azhar bin Marwan Al-Basri; has told us Muhammad bin Sawa': has told us Abu Masy'ar from Sa'id from Abu Hurairah from the Prophet Muhammad SAW he said: "You should give gifts to each other, because gifts can remove hatred in the chest, and not one underestimate the gift of his neighbor even if it is only a piece of goat leg "(HR Tirmidhi No 2065)".

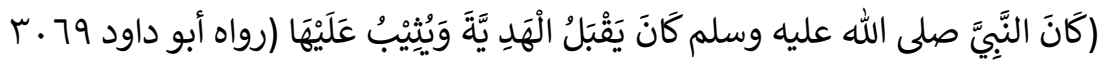

"Once the Prophet SAW, received a gift and he replied to the person who gave the gift" (HR Abu Daud No. 3069).

Furthermore, it is related to the use of shopee coins as price discounts in buying and selling transactions. In Islam, online buying and selling contracts are allowed, as described in the previous discussion. And based on the argument of Al-Qu'an Surah Al-Baqarah Verse 275: 
YVO : وَاَحَلَّ اللهُ الْبَيْعَ وَحَرَّمَ الرَّبواز (البقرة

"Allah has permitted trading and forbidden usury." (Surat al-Baqarah: 275).

According to Al-Qurthubi in a scientific journal (Busyro, 2009) states that this verse relates to the laws of usury, the permissibility of buying and selling contracts, threats to people who justify usury contracts, and the consequences experienced by the participants.

So from this verse it can be understood that Allah has justified buying and selling to His servants properly and forbade the practice of buying and selling that contains usury (Shobirin, 2015). And in QS An-Nisa Verse 29:

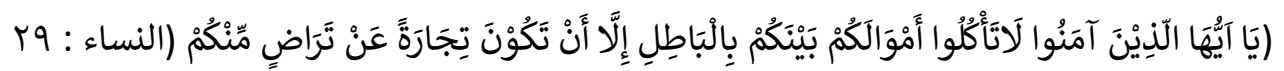

"O you who believe, do not take your neighbor's wealth in a false way (not true), except in trade that occurs on the basis of mutual consent between you" (Surah An-Nisa: 29)

In the interpretation of Ibn Kathir, it is explained that "Indeed Allah has forbidden us to eat wealth among others in a false way, while food is our most important treasure, for that it is not lawful to eat in other people's places. And do not do things that are forbidden in searching for wealth, but in a way that is prescribed by law, which happens by mutual pleasure between the seller and the buyer. So do it and make it a cause in obtaining property (Al-Shaykh, 2003) ".

Based on the explanation above, it can be concluded that buying and selling is allowed as long as it does not contain elements of gharar, usury and there is no argument against it. What is meant by gharar can be interpreted as the existence of uncertainty in the transaction between the two parties both related to the quality, quantity, price and time of delivery of goods to the detriment of one party (Karim \& Sahroni, 2016).

The use of shopee coins as discounted prices in buying and selling transactions is allowed, because the shopee coins used are obtained from cashback at the time of the previous transaction and the cashback is allowed. And there is no manipulation in the transaction because the coins are obtained from clear transactions and no party is harmed, this discount is actually a relief for the consumer and one of the advantages for the issuer because it can increase sales. In the hadith the Prophet SAW emphasized that everything that was manipulated or deceived was prohibited, as in the hadith of "Abdullah, the Prophet SAW said:

$$
\text { مَنْ غَشَّنَا فَلَيْنَ مِنَّا وَالْمَكْرُ وَالْخِدَاعُ فُ النَّارِ. }
$$

It means "whoever cheats, then he is not one of us. People who commit treason and deception, his place in hell "(HR Ibn Hibban 2:326 This hadith is valid according to al-Albani in Ash-Shahihah no. 1058). 
The results of this study are in accordance with previous research which stated that it is permissible to use shopee coins as discounted prices, namely, Lestari, Mahdiyah and Riska (2019) in their research stating that the use of shopee coins as discounted prices is permissible because it makes it easier for buyers to make shopping transactions and this coin is a discount. / discounts that users can enjoy because it is a gift given by the publisher (Lestari et al., 2019).

So it can be concluded that the provision of cashbacak promos by shopee to users is limited to giving gifts, as a marketing strategy to attract as many customers/users of the application as possible. And the use of shopee coins as discounted prices in buying and selling transactions is allowed, because the shopee coins used are obtained from cashback at the time of the previous transaction and the cashback is allowed. And there is no manipulation in the transaction because the coins are obtained from clear transactions and no party is harmed, this discount is actually a relief for the consumer and one of the advantages for the issuer because it can increase sales.

\section{Conclusion}

The cashback promo system in the form of coins and the use of coins in buying and selling transactions is provided by the shopee for free as a promotional strategy. This cashback is provided by shopee and can be used as long as the cashback voucher is still available and the user only needs to claim the available cashback voucher without any conditions. However, regarding the amount of cashback given, of course the shopee provides limitations and conditions that must be met and everything is clearly stated on each voucher. And for shopee coins, it can be used as a discount when making shopping transactions with a usage percentage of $25 \%$ of total transactions in the Shopee application and $50 \%$ of total transactions at ShopeePay Merchant. Shopee Coins can also be used $100 \%$ to buy ShopeePay Cashback vouchers and ShopeePay discount vouchers at ShopeePay Merchant. The shopee coin usage limit will expire for 3 months from the time the shopee coins are credited to the user's account, for example if the coins are obtained on a berapun date in july it will expire on 31 October. For this reason, shopee coins can only be used as long as their validity period has not expired.

In Islam, the provision of cashbacak promos by shopee parties to users is limited to giving gifts, as a marketing strategy to attract as many customers/users of the application as possible. And the use of shopee coins as discounted prices in buying and selling transactions is allowed, because the shopee coins used are obtained from cashback at the time of the previous transaction and the cashback is allowed. And there is no manipulation in the transaction because the coins are obtained from clear transactions and no party is harmed, this discount is actually a relief for the consumer and one of the advantages for the issuer because it can increase sales. 


\section{References}

Abi Bakr Ibn Muhammad Al-Husaini, IT (nd). Kifayatul Al-Akyar Juz 1. Darul IImi.

Afibatus, A., \& Taufiq, MZ (2020). The Perspective of Islamic Law on the Practice of Buying and Selling Using Discounts with Time Periods at the Ramayana Shopping Center, Salatiga City. Journal of Sharia Economic Law, 04.

Agnestia Monica, M. (2020). Thesis Analysis of Islamic Law on the Practice of Shopee PayLater Electronic Money Loans in E-Commerce.

Experts, A., \& Sunan, F. (2015). Pleasure (Antaradhin) in Buying and Selling Online. 2(1), 2015. http://weekly.cnbnews.com/news/article.html?no=124000

Al-Ansari, SAYZ (nd). Fath AI Wahab Juz 1.

Al-Ghazzi, MIQ (nd). Fath Al-Qarib Al-Mujib. Dar Al-Ihya Al-Kitab Al-Arabiyyah.

Al-Sheikh, DA bin M. bin A. bin I. (2003). Tafsir Ibn Kathir Volume 2. Imam Ash-Shafi'i Library.

Al-Sheikh, DA bin M. bin A. bin I. (2004). Tafsir Ibn Kathir Volume 6. Imam Ash-Shafi'i Library.

Ash-Shan'ani. (nd). Subulus Greetings syarh Bulughil Maram min Jam'i Adillatil Ahkam. Darul Fikr.

Az-Zuhaili, W. (2011). Islamic Fiqh Wa Adillatuhu. CV Gema Insani.

Bella, NA (2019). The Effect of Promos on Consumer Buying Interest (Study on Promotions, Cashbacks and Discounts on Consumer Buying Interests at Mister Baso Restaurant at CBD Mall Cileduk). 3, 128-140.

Busyro. (2009). Riba in the Qur'an and Sunnah. 10(1).

DSN MUI. (2000). Fatwa of the National Sharia Council Discounts in Murabaha. 16/DSN$\mathrm{MUI} / \mathrm{IX} / 200$.

Endhar, WP, Srikandi, K., \& Edy, Y. (2016). The Effect of Discounts on Purchase Intention and Its Impact on Purchase Decisions. Journal of Business Administration, 38.

Fauziah. (2020). Online Shop Business Communication Strategy "Shoppe" In Increasing Sales. $1(2), 45-53$.

Gatot, S., \& Iwan, K. (2020). Shopee's Strength As The Most Popular E-Commerce In Indonesia Today. 29.

Hasan, AF (2018). Fiqh Muammalah from Classical to Contemporary (Theory and Practice). UIN Maliki Malang Press.

Hendi, S. (2016). Fiqh Muamalah. Press Eagle. 
Jannah, M. (2020). Thesis of Mystery Box Sale and Purchase Transactions on the Shopee Site Viewed from the Perspective of Ba'i Salam.

Karim, AA, \& Sahroni, O. (2016). Riba, Gharar, and Sharia Economic Principles Analysis of Jurisprudence and Economics. Rajagrafindo Persada.

Khoshi'ah, shit. (2014). Fiqh Muamalah Comparison. Faithful Library.

Kurnia, A., \& Rahayu, S. (2020). Application of Sale and Purchase of Salam Contracts in Shopee Services. 3(2).

Kusumaningrum, DA, \& Setiawan, DP (2021). The Effect of Cashback Promos of Various Types of e-Payments on Consumer Loyalty (Case Study of Chatime Indonesia). Journal of Business Disruption, 4(2), 139-147.

Lestanti, Y. (2019). Shopee Rocking Game Coin Service Transactions on Online Buying and Selling in the Perspective of Islamic Law.

Lestari, IE, Fitriyah, M., \& Rahmawati, RF (2019). Use of Shopee Coins in Buying and Selling at Shopee. 9(1), 70-86.

Minuriha, D. (2018). Thesis Review of Islamic Law Against Buying and Selling in the Shopee Online Marketplace among UINSA Surabaya Students.

Muhammad, NH, \& Deden, MM (2013). Fiqh Legal Review of Savings and Current Accounts from Islamic Banks. 30, 22.

Nindya, H. (2019). Thesis of Engineering Sales and Purchase Practices to get Cashback at Tokopedia in Purwoketo Sharia Economic Law Perspective.

Novera, A. (2020). Thesis on Cashback System Analysis on Non-Cash Motorcycle Sale and Purchase Transactions in the Perspective of Islamic Law.

Novisari, E. (2019). The Effect of Discounts and Service Quality on Product Purchase Decisions at PT. Himalaya Drug Company. 12(02), 102.

Nur, R. (2013). Social Media-Based Online Sales in the Perspective of Islamic Economics. Journal of Islamic Law and Humanitarian Discourse, 13, 48.

Pratama, FA, Narasati, R., \& Amalia, DR (2019). The Effect of Cashback on Sales Increase Using Data Mining. 3(2), 1-5.

Rachmat, S. (2001). Fiqh Muamalah. Loyal Library CV.

Raco. (2010). Qualitative Research Method Types, Characteristics and Advantages. PT. Grasindo.

Retno, DP, \& Eliada, H. (2018). Online Buying and Selling Transactions in the Sharia Perspective of the Syafi'i Madzhab. Journal of Economics, Business, and Accounting, 20(02). 
Rusmana, I., Nasrullah, G., \& Hani, U. (2019). Islamic Law Review of Payment Application Cashback (Case Study of Go-Pay Indonesia).

Sahroni, O. (2019). Contemporary Muamalah Fiqh. Publisher Republic.

Sahroni, O. (2020). Contemporary Muamalh Fiqh Volume 3. Republika Publisher.

Salim Munir. (2017). Buying and Selling Online According to the View of Islamic Law. 6(2).

Salsabela, E. (2020). Thesis Review of Islamic Law Against Buying and Selling Practices Using Shopee PayLater.

Samsu. (2017). Research Methods Theory and Applications of Qualitative, Quantitative, Mixed Method Research, and Research and Development. Center for Religious and Social Studies (PUSAKA).

Sandu, S., \& Ali, S. (2015). Basic Research Methodology. Media Literacy Publishing.

Sari, M., \& Asmendri. (2020). Library Research (Library Research) in Science Education Research. Journal of Research in Science and Science Education, 6(01).

Sarwat, A. (2018). Fiqh Buying and selling. Fiqh Publishing House.

Shobirin. (2015). Buying and Selling in Islamic View. Journal of Islamic Business and Management, $3(2)$.

Sri, S. (2013). Contemporary Muamalah Fiqh (Vol. 53, Issue 9). http://digilib.uinsuka.ac.id/25151/1/12380073_BAB-I_IV-or-V_DAFTAR-PUSTAKA.pdf

Sugiono. (2013). Quantitative, Qualitative and R\&D Research Methods. Alphabet CV.

Sulaiman, R. (2015). Islamic Fiqh. New Rays of Algesindo.

Sulistiyawati, ES, \& Widayani, A. (2020). Shopee Marketplace as a Media for Promotion of MSME Sales in Blitar City. Journal of Marketing, 4(1), 133-142.

Suryabrata Sumadi. (2015). Research methodology. CV Rajawali Press.

Sutjipto, TS, \& Cahyono, EF (2020). Tadlis And Taghrir In Transactions On E-Marketplace. Journal of Theory and Applied Islamic Economics, 7(5), 874. https://doi.org/10.20473/vol7iss20205pp874-885

Wahyu, S. (2019). Consumer Protection Against Purchases of Goods Through Online Buying and Selling Media Judging from Law Number 19 of 2016 concerning Amendments to Law Number 11 of 2008 concerning Information and Electronic Transactions. 07(02).

Yulinda, N. (2020). Thesis on Legal Studies Giving Cashback in the Form of Points to Consumers for Online Transactions Containing Gharar Elements. 
Yunanto, R. (2020). The Role of the Marketplace as a Business Alternative in the Age of Information Technology. Journal of Scientific Computers and Informatics, 6(October 2017). https://doi.org/10.34010/komputa.v6i2.2476

Yusuf, M. (2014). Research Methods Qualitative, Quantitative, and Combined Research. date. 